Limnol. Rev. (2015) 15, 3: 95-105

\title{
Land use and land cover changes simulated with agent-based modelling for water conservation at catchment scale
}

\author{
Katarzyna Giełda-Pinas ${ }^{1}$, Arika Ligmann-Zielińska ${ }^{2}$, Zbigniew Zwoliński ${ }^{1}$ \\ ${ }^{1}$ Department of Geoinformation, Institute of Geoecology and Geoinformation, Adam Mickiewicz University in Poznań, \\ Dzięgielowa 27, 60-681 Poznań, Poland, e-mail: kasia_gp@amu.edu.pl (corresponding author), zbzw@amu.edu.pl \\ ${ }^{2}$ Department of Geography, Michigan State University, East Lansing, USA
}

\begin{abstract}
Various factors influence the spatial and temporal patterns of land cover and land use in lakeland landscapes. Land use/cover change (LUCC) is one of the crucial factors influencing both natural processes that occur in lakelands and lakes and anthropogenic processes, which intensify these changes. Therefore, LUCC at a local and regional scale may be treated as an important geoindicator for the functioning of the lakeland landscape. Nowadays, LUCC mostly depends on different human decisions. In the existing literature, the consequences of negative changes have already been widely recognized. Conversely, in this paper, we focus on the possible positive effects of LUCC. To that end, we built an agent-based model to show how selected human decisions may positively influence lakeland landscapes and lakes. We apply the model to the Gniezno Lakeland, Poland. Based on the environmental decisions of farmers, the model demonstrates how the LUCC pattern may change in time and space and how those changes may influence freshwater quality in four individual lake catchments of the Gniezno Lakeland.
\end{abstract}

Key words: agent-based modelling (ABM), lakeland landscape, lake functioning, human decision making, land use and land cover

\section{Introduction}

Water quality determines lake functioning from both the qualitative and quantitative perspective (EWFD 2000; Ferencz and Dawidek 2010; Marzin et al. 2013). Conditions of water circulation in the lake geoecosystem are determined by several biophysical features of the catchment (like its size, shape, relief, and drainage system) but, most of all, type of land use/land cover (LULC) (Strayer et al. 2003; Woli et al. 2004; Foley et al. 2005; Hillbricht-Ilkowska 2005; Williams et al. 2005; Zwoliński et al.2008). Thus human activity, especially as far as land use and land cover patterns are concerned, is the most rapid driver of global change (Slaymaker et al. 2009; Promper et al. 2014). When referring to the interaction of human and natural subsystems Rindfuss et al. (2004) show a strict relation between alterations in the land use and land cover pattern and human activity (after Promper et al. 2014).

Anthropogenic pressure, which manifests itself in land use, poses a danger to the stability of a lake's natural trophic state (Bajkiewicz-Grabowska and Zdanowski 2006; Tu and Xia 2008; Marzin et al. 2013; Bossa et al. 2014). The increase in anthropogenic action in the catchment is connected to the intensity of nutrient flow to the water body and its consequent degradation (Snyder et al. 2003; Buck et al. 2004; Morrice et al. 2008; Ferencz and Dawidek 2010). The amount of nutrients like phosphorus and nitrogen may be estimated based on the area of the most important land use/cover classes like agricultural land, forested land, pasture and fallow land, water and artificial land (Ptak and Lawniczak 2011). That makes land use and land cover crucial for freshwater functioning. Recently, however, a negative trend in human activity on lakes has begun to change due to widespread preservation activities, especially in agriculture. This process can be observed in Poland, where agriculture is the dominant land use activity (46.6\% of land is used in agriculture according to GUS 2015). The agricultural impact on water quality is especially important and, from this perspective, water may be treated as a preservation goal of most land management practices (Gascuel-Odoux et al. 2009; Helin et al. 
2013; Svoboda et al. 2013). In Poland, the regulation of rural landscape management in relation to water quality is a consequence of European, national and regional policies. The Agri-environmental Programme, implemented in 2004 (Ministry of the Environment), has a particular impact on agricultural management. The Programme offers a broad range of packages designated for farmers, where water protection is one of the most important goals (Pawlewicz and Bórawski 2013). In addition, the poor water quality of Polish lakes necessitates enacting effective management at the landscape level.

In this research, modelling was used as a major method to show the significance of LULC changes due to agricultural management. Environmental modelling is nowadays one of the most dynamic fields of research in environmental studies (Beven 2002; Malczewski 2004, 2006). The main reason for creating models is to increase knowledge about the analysed phenomenon while, at the same time, reducing the uncertainty associated with system functioning (Barnsley 2007). In particular, exploratory models are used as a laboratory to address the "what if?" questions (Klosterman 1999; Gilbert 2007). Agent-based modelling (ABM) is one of such geomodelling approaches tightly coupled with geographic information systems (Benenson et al. 2005; Brown et al. 2005; Dragicevic 2008; Crooks and Castle 2012). According to Farmer and Foley (2009, p. 685), "An agent-based model is a computerized simulation of a number of decision-makers (agents) and institutions, which interact through prescribed rules." $A B M$ is widely used in diverse fields. In geography, $\mathrm{ABM}$ uses and transforms spatial data and allows them to be exploited in various ways. ABM represents a system made from objects and elements located in a spatial model environment (Ligmann-Zielińska 2010). Agents are the core of ABM and represent the decision-making individuals who play a crucial role in model building and simulations (Dzieszko et al. 2013). In the model, agents may undertake an action, learn about a model environment and make decisions to achieve their goals. The process of decision making and the consequences of that process are what distinguish ABM from other modelling approaches. Therefore, we chose ABM as the most suitable method to represent a system (lake catchment) where a group of decision makers, like farmers, plays a significant role in changing the use of land.

In this paper, we describe an $\mathrm{ABM}$ created to simulate spatiotemporal land use/cover changes, which are treated as combined geoindicators for changes in the geographic environment (Zwoliński 1998). With the ABM, we design three simulated land use scenarios, which are then used to calculate the annual leaching of nutrients from each catchment to its lake.

\section{Study area}

The Gniezno Lakeland in Poland was selected as a study area. The selection criteria were as follows: 1) a lakeland, with diversity of lake sizes, nutrient concentrations, and catchment land use patterns (GiełdaPinas 2012), 2) the predominantly agricultural character of the region (Giełda-Pinas 2012), and 3) locations where Agri-environmental Programme participation has been significantly increasing.

The model is designated for the whole study area with the possibility of using it for smaller parts like individual catchments. For the purposes of this paper, we selected an area of approximately 5,000 hectares, which amounts to four lake catchments. The selection criteria included only lake catchments and catchments located in close proximity to each other. The final selection contains Lake Budzisławskie (1), Lake Wiczyńskie (2), Lake Kosewskie (3), and Lake Kownackie (4) (Fig. 1 and Table 1).

Table 1. Selected characteristics of lakes and their catchments (based on MPHP 2007, and Choiński 2007)

\begin{tabular}{|c|c|c|c|c|c|c|c|c|}
\hline \multirow{2}{*}{\multicolumn{3}{|c|}{ Lake }} & \multicolumn{6}{|c|}{ Catchment } \\
\hline & & & \multirow{2}{*}{ Area } & \multicolumn{5}{|c|}{ Land use and land cover } \\
\hline Name & Area & Mean depth & & Agricultural & Forest & Pasture and fallow & Water & Artificial \\
\hline & [ha] & [m] & & & & [ha] & & \\
\hline Budzisławskie & 153.45 & 10.8 & 802.21 & 264.72 & 159.12 & 165.43 & 212.94 & 0.00 \\
\hline Wilczyńskie & 199.28 & 7.8 & 561.30 & 222.72 & 71.28 & 46.33 & 220.97 & 0.00 \\
\hline Kosewskie & 87.50 & 5.9 & 1884.60 & 996.65 & 306.92 & 170.63 & 402.98 & 7.42 \\
\hline Kownackie & 86.12 & 6.5 & 1880.63 & 773.13 & 615.57 & 111.71 & 321.69 & 58.53 \\
\hline
\end{tabular}




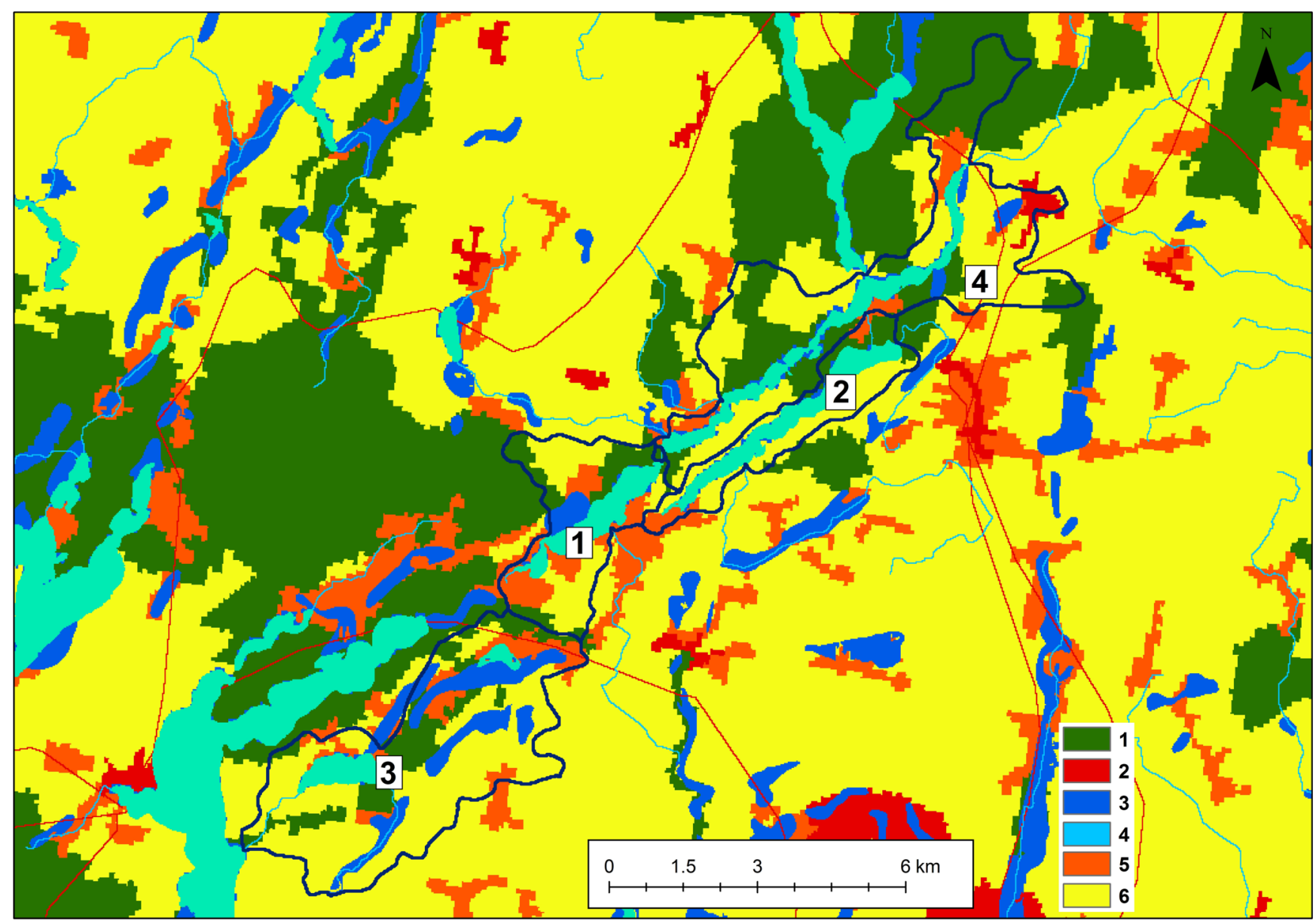

Fig. 1. Study area: lakes with their catchments (1- Budzisławskie, 2 - Wilczyńskie, 3 -Kosewskie, 4-Kownackie). Legend: 1 - forest, 2 urban area (artificial), 3 - wetlands 4 - lakes and rivers, 5 - fallow land, 6 - arable land

\section{Methods}

\section{Conceptual model}

The model presented in this paper is a representation of the process of farmers' decisions to participate in a land conservation programme called the Agri-environmental Programme (packages designated for water conservation) and the accompanying Afforestation Programme as well as their consequences on land use/cover change and water quality.

The model contains two types of agents: the decision-making agent called the Farmer-agent and an assistant agent called the Parcel-agent. Each parcel is described by its geographic coordinates and farmer ownership. In addition, each Parcel-agent receives and stores information about its distance to water (rivers, lakes, small ponds) and forest, coming from GIS layers (Figs 2 and 3). The major goal of the Farmer-agents is to make a decision about participation in the Programme. The number of Farmer-agents who want to enrol is set by the modeller based on a judgement of the profits that the farmer can achieve from the enrolment, taking into account farmers' environmental concerns. A Farmer-agent may decide to enrol to the Programme if his specific parcel meets the requirements of the Programme packages.

The group of Farmer-agents is responsible for the changes that occur in the modelled environment during model execution. The results are reflected in land use/cover, because when the Farmer-agent decides to participate in the Programme and his/her parcel (Parcel-agent) meets the requirements of the Programme there are changes in land use/cover on that parcel due to a new and different management strategy. Specifically, when the Farmer-agent joins Package 9 a buffer zone around the lake, river or pond is created and arable land changes to forest. When he/she joins Packet 8 , arable land is converted to pasture and fallow, and when the farmer joins the Afforestation Programme his/her arable land changes to forest (Fig. 4). 


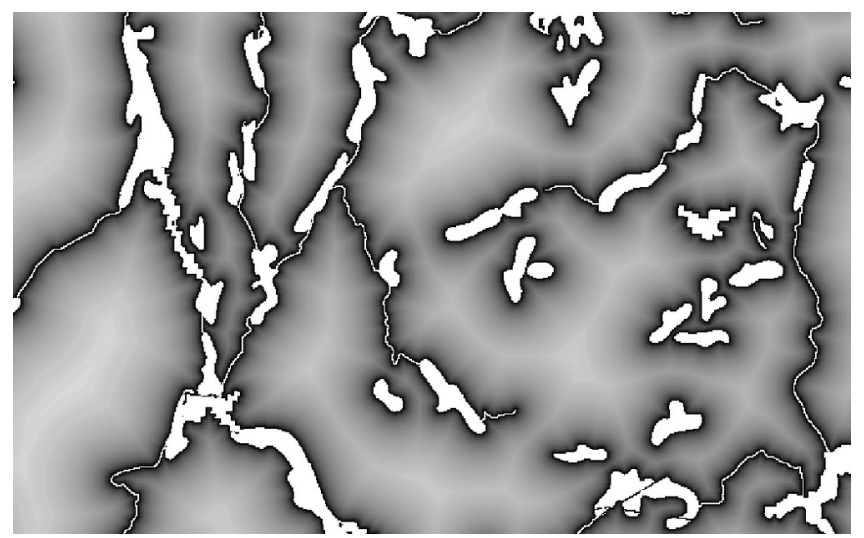

Fig. 2. Example of the water distance layer (darker colour - closer to water bodies)

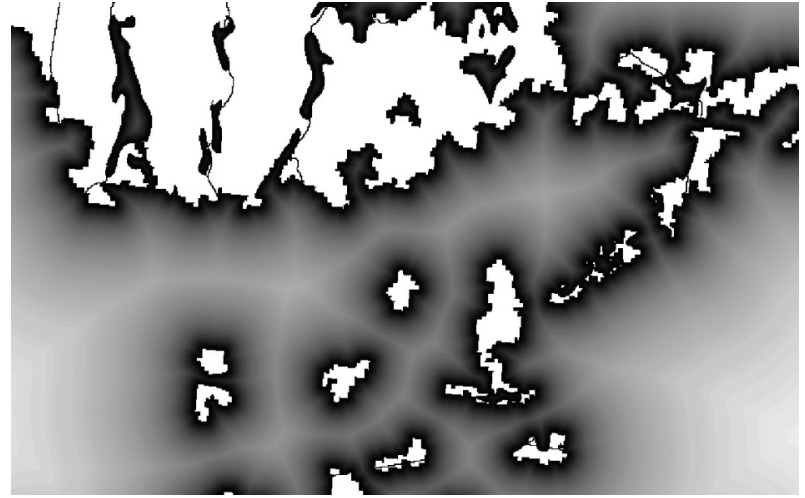

Fig. 3. Example of the forest distance layer (darker colour - closer to forest)

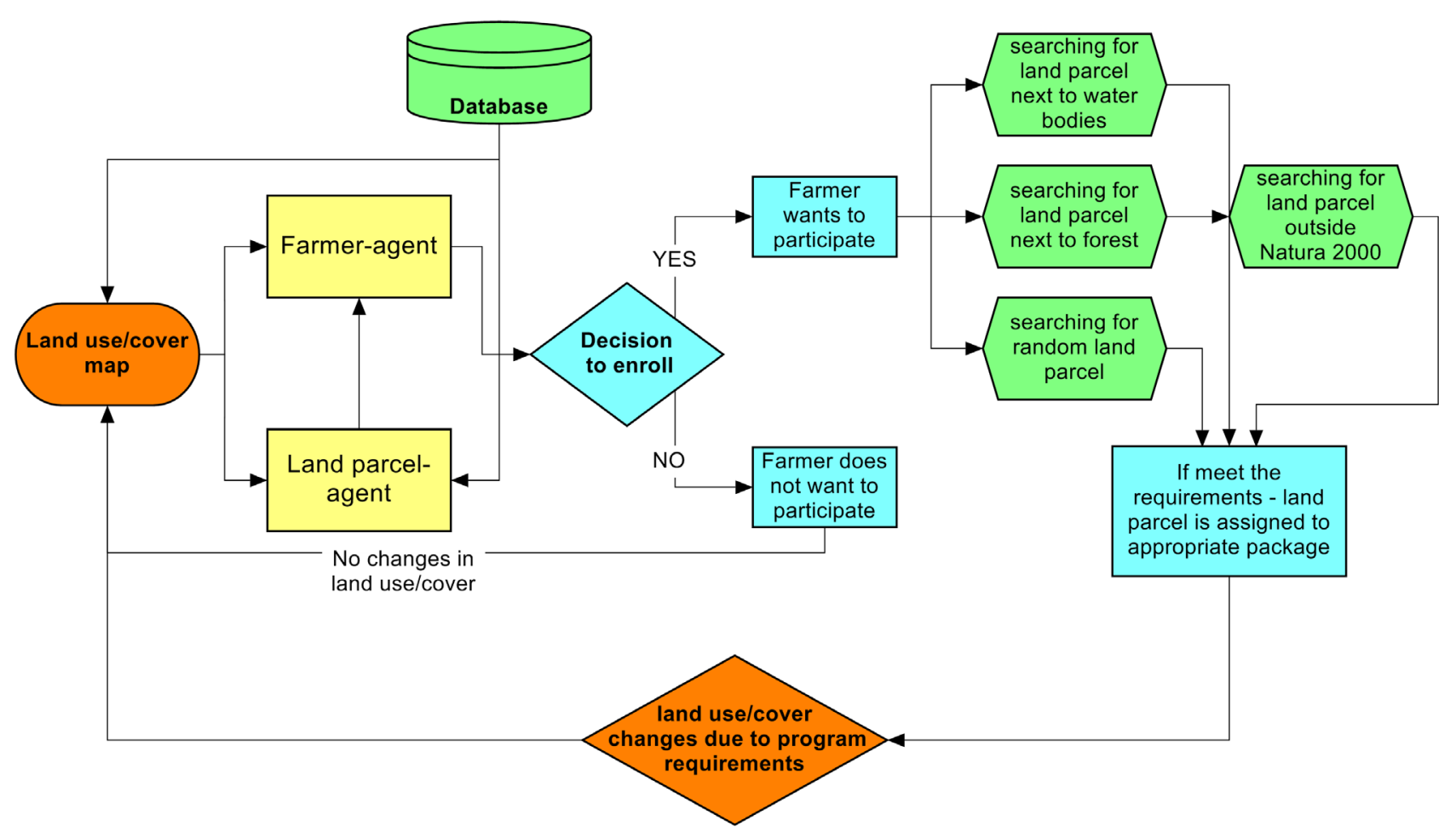

Fig. 4. Decision process used in the ABM

\section{Operational scenarios}

In this research, we use ABM to perform scenario analysis. The analysis based on scenarios serves as a tool to determine what could happen given different configurations of decision factors and/or their different importance (Verburg et al. 2008). Based on survey results, the most important factors in the farmers' decision-making process are both high profit (the amount of money that the farmer may receive from the Agency) and his/her environmen- tal concern. Theoretically, by changing both values, i.e. increase or decrease in actual payment and environmental concern, we can determine hypothetical scenarios of farmers' enrolment (i.e. establish the approximate number of Farmer-agents that decide to participate). We used these survey observations together with information about the actual proportion of farmer participation in the Programme in the Gniezno Lakeland District to develop three different future land use scenarios. 
Scenario 1: In the "positive scenario" the profit from the Programme is higher than what the Agency offers and farmers care about conservation. We estimate that around $10 \%$ of the whole group will decide to enrol in the Programme in this future scenario.

Scenario 2: The "neutral scenario" is established by the census data. We used the actual number of farmers (farms) in Wielkopolska (Greater Poland) region (where the lakes are located) i.e. 162,672 (USP 2012) and the average number of farmers that actually enrolled in the Agri-environmental Programme in 2007 (1,669 - Package 8 and Package 9, 123 - Afforestation Programme). That gave us $1 \%$ of farmers interested in the Programme.

Scenario 3: In the "negative scenario", we assumed that a small number of farmers want to join the Programme. Farmers are also less aware of the environmental issues or the potential profit from the investment is smaller. We assumed that in this scenario around $0.1 \%$ will join.

Water quality

The major premise for water conservation in this paper is that lake functioning is strongly dependent on the land use in the catchment, especially as regards nutrient pollution sources, mainly from agriculture (Snyder et al. 2003; Buck et al. 2004; Morrice et al. 2008; Ferencz and Dawidek 2010). Ptak and Ławniczak (2011) estimated the amount of the annual nutrient leaching from the different types of areas in the Polish Lowland. This amount of nutrient was based on previous fieldwork reported in Kajak (1979), Ryding and Rast (1989) and Bajkiewicz-Grabowska (2002). We used this data to approximate the amount of nitrogen and phosphorus that enters the four lakes each year (the average amount per hectare was multiplied by the area of each land use/cover in the catchment). For each catchment we used four maps of land use/cover: "before simulations" and after scenariobased ABM simulations, to calculate the differences in annual yielding.

\section{Results and discussion}

\section{Spatial pattern}

Based on the assumptions in the three future scenarios, a different number of farmers are interested in the Agri-environmental Programme. Consequently, in the model, a different number of Farmer-agents show interest in participating each time. The results are different simulated land use/cover pattern maps (Fig. 5).

The spatial distribution of different land use/ cover classes in each scenario depends mainly on the topographic factors, because of the two parameters, distance to water and distance to forest, which are the key factors to determine participation in two of the three Programme packages. In the model, each Farmer-agent first makes a decision whether to participate in the Programme, and second checks if their parcels meet the requirements of at least one of the Programme options:

$\Rightarrow$ Package 8 Soil and water protection,

$\Rightarrow$ Package 9 Buffer zones,

$\Rightarrow$ Afforestation Programme.

Most of the changes in land use are spatially dependent; the buffer zones are located next to water bodies, and a new forest is placed next to the edge of one already existing. When choosing a parcel for
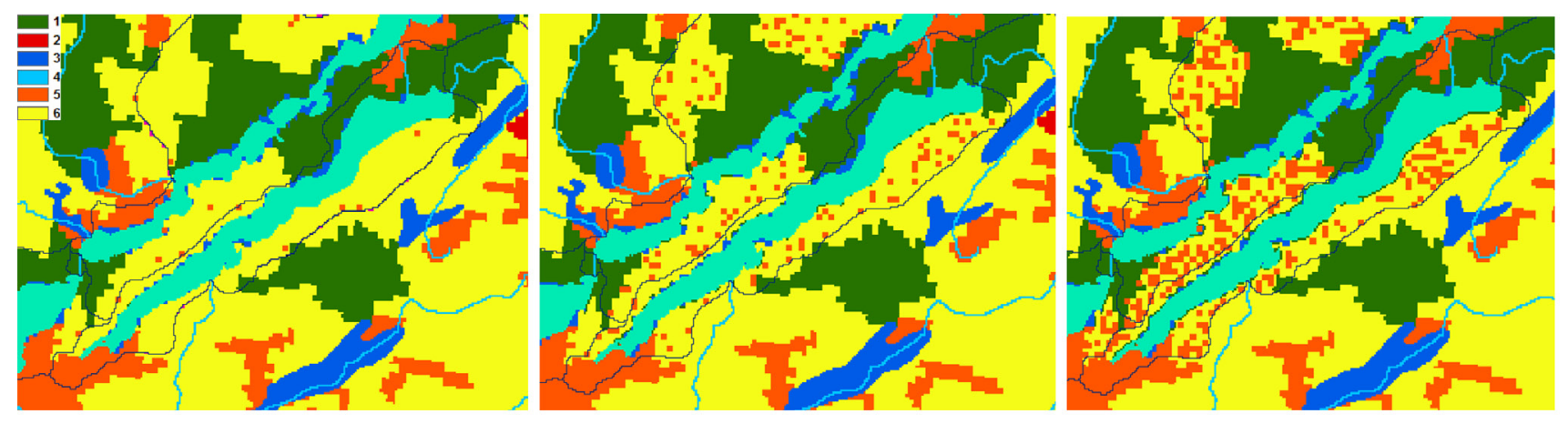

Fig. 5. Example of output maps with different land use/cover patterns in three different scenarios for Lake Wilczyńskie (from the left: "negative”, “neutral", "positive”) Legend: 1 - forest, 2 - urban area (artificial), 3 - wetlands 4 - lakes and rivers, 5 -fallow land, 6 - arable land 
soil and water protection - package 8 - those parcels are disturbed randomly, because there are no restrictions in the Programme concerning localization. The idea of this package is to plan pioneer crops in the fields (land parcels) with a minimum size of 1 ha. This model behaviour can be justified by the nature of this package. Winter vegetation is planted in fields mainly to prevent erosion, which is also used afterwards as natural compost. Because there are strict planning rules for different crops (resulting from the specifics of the crop), and due to crop rotation, the regional pattern of parcels chosen for this package does not demonstrate any observable spatial clustering and the resulting land use change patterns are mostly dependent on the biophysical characteristics of land enrolled in conservation.

\section{Changes in land use}

The simulated future land use/cover development of the different lake catchments is summarized in Table 2. According to our research goal, we would expect that the simulated changes have a positive effect on the lakes due to a relative increase in forest, pasture, and fallow and a relative decrease in agricultural land, which would result in decreasing matter supply to the lake (Table 2). Below, we compare the differences among the scenarios and attempt to explain the reasons behind such model behaviour.

In general, the simulated changes in the studied catchments reflect the assumptions made during the development of the model, i.e., an increase in forest, pasture and fallow land at the expense of the (lost) arable land. However, in absolute numbers, the changes within catchments range from moderate to negligible. For example, for Lake Wilczyńskie, small differences exist among the scenarios. In the negative scenario, the differences between "before" and "after" are very minimal: less than 0.5 ha for forest and 3.19 ha for pasture and fallow $(0.1 \%$ and $0.1 \%$ of the entire catchment, respectively). In the "neutral" scenario, the changes in both types of land use/cover reach 32 ha (5.7\% of the catchment area). In the "positive" scenar-

Table 2. Changes in land use for lake catchments before and after simulation

\begin{tabular}{|c|c|c|c|c|c|c|}
\hline \multirow{3}{*}{ Simulations } & \multicolumn{6}{|c|}{ Catchments } \\
\hline & \multirow{2}{*}{ Total area } & \multicolumn{5}{|c|}{ Land use } \\
\hline & & Agricultural & Forest & Pasture and fallow & Water & Artificial \\
\hline & \multicolumn{6}{|c|}{ [ha] } \\
\hline \multicolumn{7}{|c|}{ Budzisławskie } \\
\hline Before changes & 802.21 & 264.72 & 159.12 & 165.43 & 212.94 & 0.00 \\
\hline Scenario 1 "positive" & & 167.23 & 167.32 & 254.72 & 212.94 & 0.00 \\
\hline Scenario 2 "neutral" & & 231.24 & 164.12 & 193.91 & 212.94 & 0.00 \\
\hline Scenario 3 "negative" & & 261.81 & 159.30 & 168.16 & 212.94 & 0.00 \\
\hline \multicolumn{7}{|c|}{ Wiczyńskie } \\
\hline Before changes & 561.30 & 222.72 & 71.28 & 46.33 & 220.97 & 0.00 \\
\hline Scenario 1 "positive" & & 150.65 & 87.48 & 102.20 & 220.97 & 0.00 \\
\hline Scenario 2 "neutral" & & 190.76 & 78.95 & 70.62 & 220.97 & 0.00 \\
\hline Scenario 3 "negative" & & 218.95 & 71.86 & 49.52 & 220.97 & 0.00 \\
\hline \multicolumn{7}{|c|}{ Kosewskie } \\
\hline Before changes & 1884.60 & 996.65 & 306.92 & 170.63 & 402.98 & 7.42 \\
\hline Scenario 1 "positive" & & 622.74 & 334.79 & 516.67 & 402.98 & 7.42 \\
\hline Scenario 2 "neutral" & & 847.27 & 317.65 & 309.28 & 402.98 & 7.42 \\
\hline Scenario 3 "negative" & & 982.28 & 307.53 & 184.39 & 402.98 & 7.42 \\
\hline \multicolumn{7}{|c|}{ Kownackie } \\
\hline Before changes & 1880.63 & 773.13 & 615.57 & 111.71 & 321.69 & 58.53 \\
\hline Scenario 1 "positive" & & 467.29 & 641.68 & 391.44 & 321.69 & 58.53 \\
\hline Scenario 2 "neutral" & & 655.51 & 625.13 & 219.77 & 321.69 & 58.53 \\
\hline Scenario 3 "negative" & & 760.16 & 615.96 & 124.29 & 321.69 & 58.53 \\
\hline
\end{tabular}


io, the changes in land use/cover are 16.2 ha for forest and 55.87 ha for pasture and fallow, which amounts to a $13 \%$ decrease in agricultural land.

When considering all four catchments and the best-case "positive" scenario, the forested land increased on average by about $1.7 \%$ (from $20.4 \%$ to $22.1 \%)$. The increase in pasture and fallow land was much higher than in the case of forest, on average by approximately $13.5 \%$. That means that from the $41.7 \%$ which agricultural land covered only $26.4 \%$ remained (Table 2 when converted to \%).

In the "neutral" scenario, we can still observe some noticeable increase in pasture and fallow land by about $5.2 \%$ (from $11 \%$ to $16.2 \%$ on average); however, the forested land only increased by about $0.8 \%$ (from $20.4 \%$ to $21.2 \%$ ). Thus, the total agricultural land also decreased considerably (from $41.7 \%$ to $35.7 \%$ ).

In the "negative" scenario, the changes in land use are minimal suggesting that the scenario has no effect on land conservation. The agricultural area decreased on average by $0.62 \%$, which translates to an increase of $0.04 \%$ in forest and $0.62 \%$ in pasture and fallow. That is not surprising because very few farmers decided to enrol in the Programme and the potentially enrolled land does not meet the requirements of the more demanding packages like package 9 and planting new forest.

When comparing the individual catchments, the greatest changes in forestland can be observed for Lake Wilczyńskie catchment. In the "positive" scenario, the change was rapid at the beginning of the simulation (from $2.9 \%$ to $12.7 \%$ ) and then gradually increased to $15.6 \%$ at the end of the model run. We hypothesize that this relatively large increase in forest may be caused by the high suitability of land in the catchment for package 9 Buffer zones - the long shore of Lake Wilczyńskie. For pasture and fallow, the most significant change was in Lake Kosewskie catchment - an increase from 5.9 to $20.8 \%$. While this change is substantial, we would like to point out that, in this catchment, the area of pasture/fallow was relatively small before simulation. Together with the largest agricultural area among the catchments, the opportunity for change was the greatest. Specifically, when a similar number of farmers from different catchments want to enrol, the farmers in Lake Kosewskie catchment have the most land that can be converted. The smallest changes in land use can be observed in Lake Budzisławskie catchment. The growth in pasture and fallow took $11.4 \%$ and forest $1.1 \%$ of the agricultural land. The reason for this may be the relatively small amount of agricultural class at the beginning of the simulation and, in consequence, the least opportunity for change.

\section{Changes in nutrient yields}

To estimate changes in the amount of nitrogen and phosphorus that enters the four lakes each year, maps of the simulated future land use/cover development were used. The results are included in Table 3.

The results show that, in all catchments, there were changes in nutrient yields to lakes. A larger absolute decrease in the lakes Kosewskie and Kownackie probably resulted from a larger catchment area. On average, the phosphorus yield shows around a $13.1 \%$ decrease in the "positive" scenario, $6 \%$ decrease in the "neutral" scenario, and only $0.5 \%$ in the "negative" scenario (Fig. 6).

Compared to phosphorus, nitrogen yields are in total much larger, but the before and after simulation differences are generally smaller (Fig. 7). In the "positive" scenario in all four catchments, the changes are on average only $5.3 \%$. In the "neutral" scenario it is $2.1 \%$ and in the "negative" one, $0.2 \%$. Although the differences are on average small, they do differ among lakes. Specifically, for the Lake Kosewskie catchment, they may reach almost $7 \%$, which may be associated with the large catchment area and more opportunities for land use changes during the simulation process.

\section{Conclusions}

In this paper, we report on an agent-based model created to simulate future changes in land use due to farmers' environmental decisions on participating in the E.U. Agri-environmental Programme implemented in Poland. The model simulates different land use/ cover patterns and allows changes in nutrient flows from the catchment to the lake to be calculated.

We considered four lake catchments from Gniezno Lakeland District in Poland. For every catchment, we ran three distinct scenario-based simulations ("positive", "neutral", and "negative") resulting in different patterns of land use. The simulated land use transformation was notable and plausible. On average, in the best-case "positive" scenario, $13.5 \%$ of land changed from agricultural to pasture/fallow, and $1.7 \%$ changed from agricultural to forest.

When comparing nutrient flow, the changes are less noticeable, possibly because the nutrients $(\mathrm{P}, \mathrm{N})$ 
Table 3. The approximate yield $\left[\mathrm{kg} \mathrm{ha}^{-1} \mathrm{yr}^{-1}\right]$ of nitrogen $(\mathrm{N})$ and phosphorus (P) for analysed lakes (total yield before changes is based on data of Ptak and Ławniczak 2011)

\begin{tabular}{|c|c|c|c|c|c|c|c|c|}
\hline \multirow{5}{*}{ Lake } & & \multicolumn{7}{|c|}{ Catchment } \\
\hline & & \multirow{2}{*}{ Total yield } & \multicolumn{6}{|c|}{ Land use } \\
\hline & & & \multirow{2}{*}{$\begin{array}{c}\text { Agricultural } \\
0.56\end{array}$} & \multirow{2}{*}{$\begin{array}{c}\text { Forest } \\
0.20\end{array}$} & \multirow{2}{*}{$\begin{array}{c}\text { Pasture and fallow } \\
0.30\end{array}$} & \multirow{2}{*}{$\begin{array}{l}\text { Water } \\
0.00\end{array}$} & \multirow{2}{*}{\multicolumn{2}{|c|}{$\begin{array}{c}\text { Artificial } \\
0.90\end{array}$}} \\
\hline & & $\mathrm{P}$ & & & & & & \\
\hline & & $\mathrm{N}$ & \multicolumn{2}{|l|}{10.10} & 8.00 & \multirow[t]{2}{*}{0.00} & \multicolumn{2}{|r|}{6.00} \\
\hline \multicolumn{8}{|c|}{ Before changes } & \\
\hline \multirow{2}{*}{ Budzisławskie } & $\mathrm{P}$ & 230 & 148 & 32 & 50 & & 0 & 0 \\
\hline & $\mathrm{N}$ & 5031 & 2674 & 1034 & 1323 & & 0 & 0 \\
\hline \multirow{2}{*}{ Wiczyńskie } & $\mathrm{P}$ & 153 & 125 & 14 & 14 & & 0 & 0 \\
\hline & $\mathrm{N}$ & 3083 & 2249 & 463 & 371 & & 0 & 0 \\
\hline \multirow{2}{*}{ Kosewskie } & $\mathrm{P}$ & 677 & 558 & 61 & 51 & & 0 & 7 \\
\hline & $\mathrm{N}$ & 13471 & 10066 & 1995 & 1365 & & 0 & 45 \\
\hline \multirow{2}{*}{ Kownackie } & $P$ & 642 & 433 & 123 & 34 & & 0 & 53 \\
\hline & $\mathrm{N}$ & 13055 & 7809 & 4001 & 894 & & 0 & 351 \\
\hline \multicolumn{9}{|c|}{ Scenario 1 "positive" } \\
\hline \multirow{2}{*}{ Budzisławskie } & $\mathrm{P}$ & 204 & 94 & 33 & 76 & & 0 & 0 \\
\hline & $\mathrm{N}$ & 4814 & 1689 & 1088 & 2038 & & 0 & 0 \\
\hline \multirow{2}{*}{ Wiczyńskie } & $\mathrm{P}$ & 133 & 84 & 18 & 31 & & 0 & 0 \\
\hline & $\mathrm{N}$ & 2908 & 1522 & 569 & 818 & & 0 & 0 \\
\hline \multirow{2}{*}{ Kosewskie } & $P$ & 577 & 349 & 67 & 155 & & 0 & 7 \\
\hline & $\mathrm{N}$ & 12644 & 6290 & 2176 & 4133 & & 0 & 45 \\
\hline Kanneli. & $\mathrm{P}$ & 560 & 262 & 128 & 117 & & 0 & 53 \\
\hline 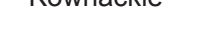 & $\mathrm{N}$ & 12373 & 4720 & 4171 & 3132 & & 0 & 351 \\
\hline & & & Scenario 2 & utral" & & & & \\
\hline O & $P$ & 220 & 129 & 33 & 58 & & 0 & 0 \\
\hline 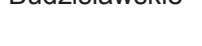 & $\mathrm{N}$ & 4954 & 2336 & 1067 & 1551 & & 0 & 0 \\
\hline blioz ŕ́tri & $\mathrm{P}$ & 144 & 107 & 16 & 21 & & 0 & 0 \\
\hline VUIC & $\mathrm{N}$ & 3005 & 1927 & 513 & 565 & & 0 & 0 \\
\hline Kor & $P$ & 637 & 474 & 64 & 93 & & 0 & 7 \\
\hline RUSEVUSTIE & $\mathrm{N}$ & 13141 & 8557 & 2065 & 2474 & & 0 & 45 \\
\hline Kounnti. & $\mathrm{P}$ & 611 & 367 & 125 & 66 & & 0 & 53 \\
\hline RUWHICKIE & $\mathrm{N}$ & 12793 & 6621 & 4063 & 1758 & & 0 & 351 \\
\hline & & & Scenario 3 & gative" & & & & \\
\hline$\Omega_{0}$ & $P$ & 229 & 147 & 32 & 50 & & 0 & 0 \\
\hline & $\mathrm{N}$ & 5025 & 2644 & 1035 & 1345 & & 0 & 0 \\
\hline bliozúntri & $\mathrm{P}$ & 152 & 123 & 14 & 15 & & 0 & 0 \\
\hline VUICLYISKIE & $\mathrm{N}$ & 3075 & 2211 & 467 & 396 & & 0 & 0 \\
\hline Kore & $\mathrm{P}$ & 674 & 550 & 62 & 55 & & 0 & 7 \\
\hline RUDervonic & $\mathrm{N}$ & 13440 & 9921 & 1999 & 1475 & & 0 & 45 \\
\hline Kart & $\mathrm{P}$ & 639 & 426 & 123 & 37 & & 0 & 53 \\
\hline NuvUILCKIE & $\mathrm{N}$ & 13027 & 7678 & 4004 & 994 & & 0 & 351 \\
\hline
\end{tabular}




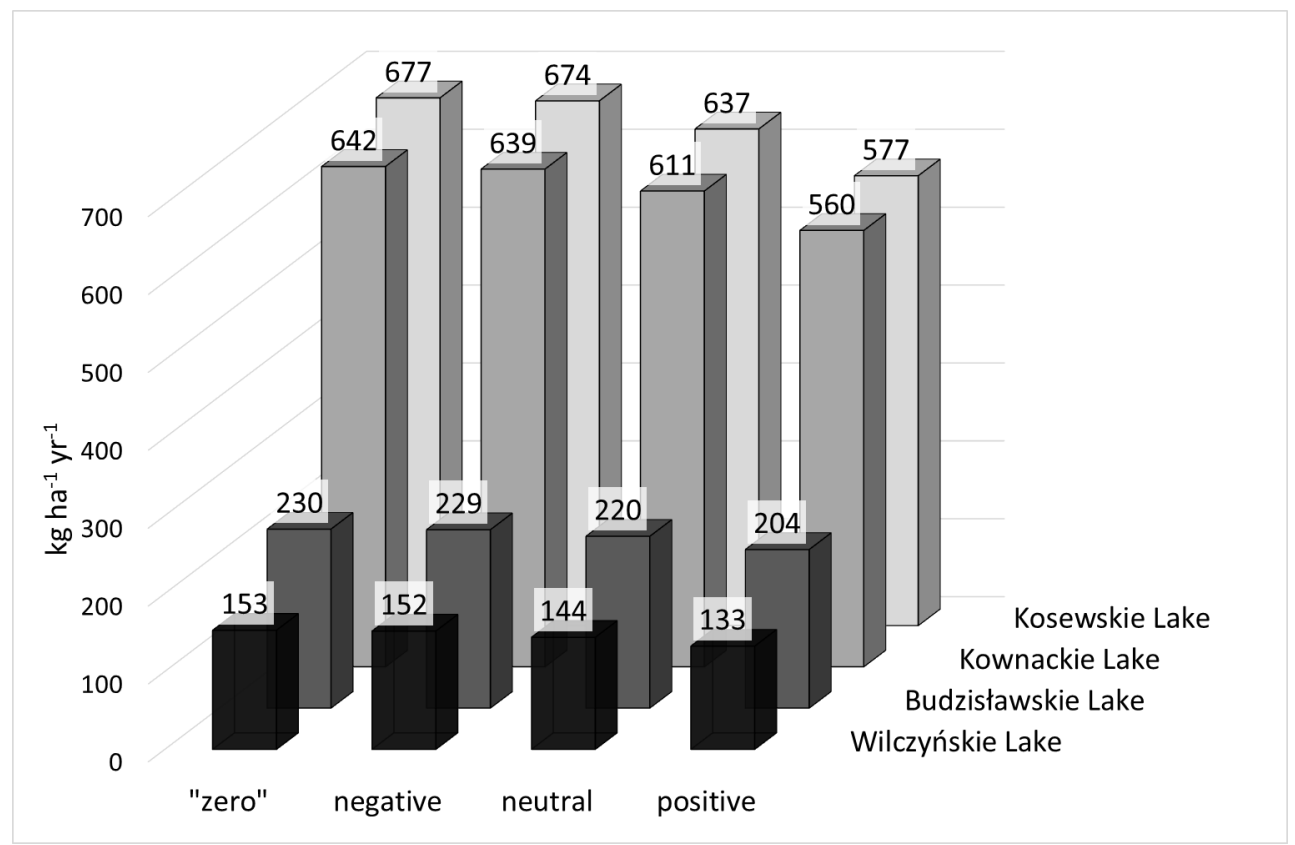

Fig. 6. Phosphorus yield $\left[\mathrm{kg} \mathrm{ha}^{-1} \mathrm{yr}^{-1}\right]$ for analysed lakes before and after simulations

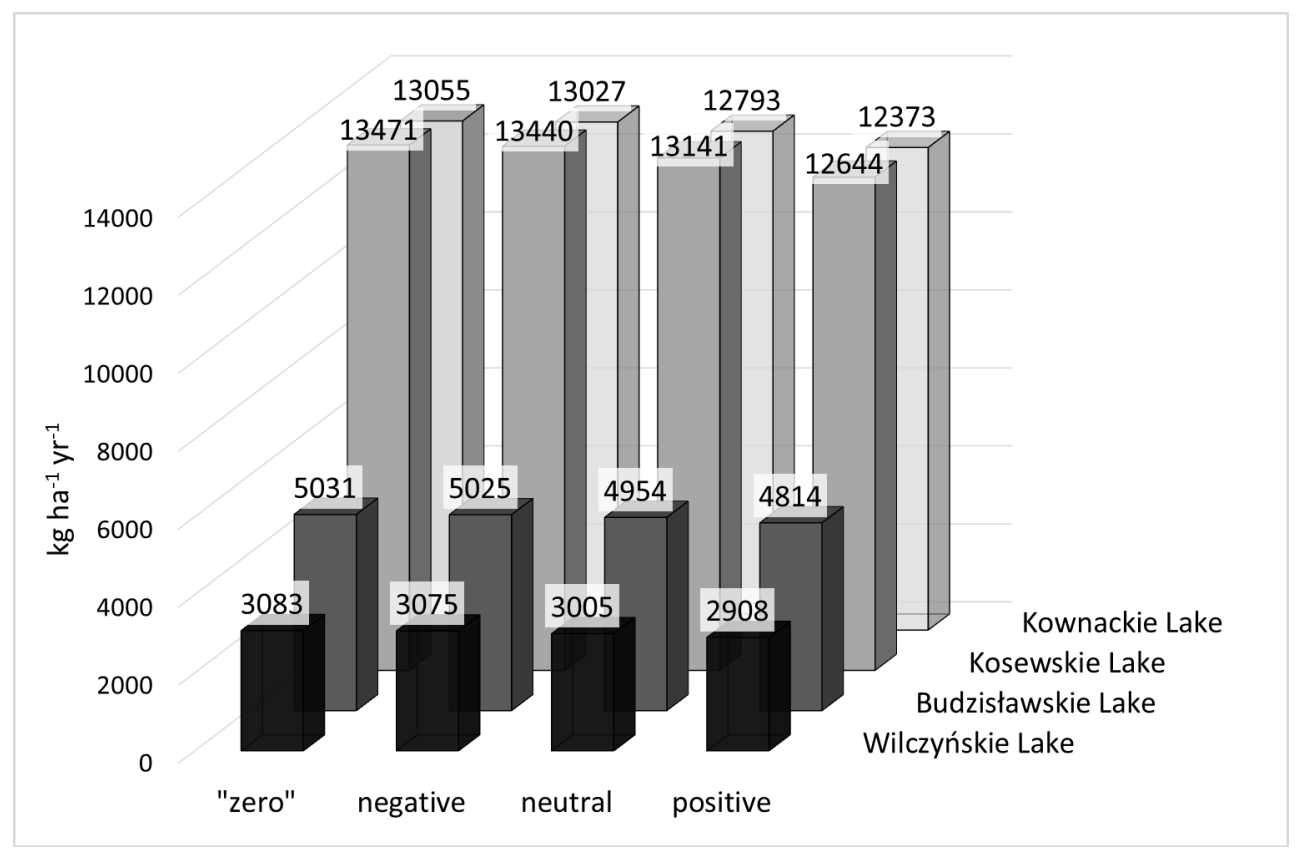

Fig. 7. Nitrogen yield $\left[\mathrm{kg} \mathrm{ha}^{-1} \mathrm{yr}^{-1}\right]$ for analysed lakes before and after simulations

are released from all land use/cover classes (forest, pasture and fallow, agricultural and artificial) and the relatively small percentage of change in land use per catchment cannot warrant significant nutrient yield reduction. Regardless of the small changes, they show the environmental benefits of farmers' decision making when the "positive" scenario is applied. This may lead to more informed policymaking and to preparation of environmentally suitable and profitable offers that could positively affect water quality. 
Monitoring and modelling land use/cover development on a regional scale has been carried out around the world (Rembold et al. 2000; Ruelland et al. 2010; Promper et al. 2014). The focus is usually on deforestation, with water functioning becoming more and more popular in recent years (Valbuena 2010). In Polish conditions, where the total area of woodlands is gradually growing every year, agricultural problems and their influence on the environment may be the most important questions for environmental scientists. In this respect the new approaches to modelling, like agent-based modelling, hold promise for addressing human-environmental research problems.

\section{References}

Bajkiewicz-Grabowska E., 2002, Obieg materii w ekosystemach rzeczno-jeziornych (Circulation of matter in the river-lake systems), Wydaw. UW, Warszawa, pp. 274 (in Polish, English summary).

Bajkiewicz-Grabowska E., Zdanowiski B., 2006, Phosphorus retention in lake sections of Struga Siedmiu Jezior, Limnol. Rev. 6: 5-12.

Barnsley M.J., 2007, Environmental modelling: A practical introduction, CRC Press, Boca Raton, pp. 432.

Benenson I., Aronovich S., Noam S., 2005, Let's talk objects: generic methodology for urban high-resolution simulation, Comput. Environ. Urban Syst. 29(4): 425-453.

Beven K., 2002, Towards a coherent philosophy for modelling the environment, Proc. R. Soc. Lond. A 458: 24652484.

Bossa A.Y., Diekkrüger B., Agbossou E.K., 2014, Scenariobased impacts of land use and climate change on land and water degradation from the meso to regional scale, Water 6(10): 3152-3181.

Brown D.G., Riolo R., Robinson D.T., North M., Rand W., 2005, Spatial process and data models: Toward integration of agent-based models and GIS, J. Geogr. Syst. 7(1): 25-47.

Buck O., Niyogi D.K., Townsend C.R., 2004, Scale dependence of land use effects on water quality of streams in agricultural catchments, Environ. Pollut. 130: 287-299.

Choiński, A., 2007, Katalog jezior Polski (Catalogue of Polish lakes), Wydaw. Nauk. UAM, Poznań, pp. 600 (in Polish).

Crooks A.T., Castle C., 2012, The Integration of Agent-Based Modeling and Geographical Information for Geospatial Simulation, [in:] Heppenstall A.J., Crooks A.T., See L.M., Batty M. (eds), Agent-Based Models of Geographical Systems, Springer, Dordrecht: 219-252.

Dragicevic S., 2008, GeoComputation: Modeling with spatial agents, Comput. Environ. Urban Syst. 32(6): 415-416.

Dzieszko P., Bartkowiak K., Giełda-Pinas K., 2013, Agenci w modelowaniu agentowym (Agents in agent-based modeling), Rocz. Geomat. 11(4): 17-23.
[EWFD] European Water Framework Directive, 2000, Directive 2000/60/EC of the European Parliament and of the Council of 23 October 2000 establishing a framework for Community action in the field of water policy, Offic. J. Eur. Union L327 43: 1-72.

Farmer J.D., Foley D., 2009, The economy needs agent-based modelling, Science 460: 685-686.

Ferencz B., Dawidek J., 2010, Spatial variation of basin supply as a factor of water quality in a shallow, flow-through lake, Limnol. Rev. 10(3-4): 127-132.

Foley J.A., DeFries R., Anser G.P., Barford C., Bonan G., Carpenter S.R., Chapin F.S., Coe M.T., Daily G.C., Gibbs H.K., 2005, Global consequences of land use, Science 309: 570-574.

Gascuel-Odoux C., Massa F., Durand P., Merot P., Troccaz O., Baudry J., Thenail C., 2009, Framework and tools for agricultural landscape assessment relating to water quality protection, Environ. Manag. 43:921-935.

Giełda-Pinas, K. 2012, Waloryzacja przyrodnicza krajobrazu Pojezierza Gnieźnieńskiego (Landscape natural values assessment of Gniezno Lakeland), Probl. Ekologii Kraj. 33: 77-85 (in Polish, English summary).

Gilbert N., 2007, Agent-based models, Sage Publ. Inc., London.

[GUS] Główny Urząd Statystyczny (Central Statistical Office), 2015, Poland in figures, Wydaw. GUS, Warszawa, pp. 39 (in Polish and English).

Helin J., Hyytiäinen K., Korpela E., Kuussaari M., 2013, Model for quantifying the synergies between farmland biodiversity conservation and water protection at catchment scale, J. Environ. Manag. 131:3 07-317.

Hillbricht-Ilkowska A., 2005, Ochrona jezior i krajobrazu pojeziernego - problemy, procesy, perspektywy (Protection of lakes and lakelands: problems, processes, perspectives), Kosmos 54(2-3): 285-302 (in Polish, English summary).

Kajak Z., 1979, Eutrofizacja jezior (Eutrophication of lakes), Wydaw. PWN, Warszawa, pp. 232 (in Polish).

Klosterman R.E., 1999, The what if? collaborative planning support system, Environ. Plann. B 26(3): 393-408.

Ligmann-Zielińska A., 2010, Agent-based models, [in:] Warf B. (ed.) Encyclopedia of Geography, Sage Publ. Inc.. Retrieved from http://www.sage-ereference.com/ geography/Article n14.html

Malczewski J., 2004, GIS-based land-use suitability analysis: a critical overview, Progr. Plann. 62(1): 3-65.

Malczewski J., 2006, GIS-based multi-criteria decision analysis: a survey of the literature, Int. J. Geogr. Inform. Syst. 20(7): 703-726.

Marzin A., Verdonschot P.F.M., Pont D., 2013, The relative influence of catchment, riparian corridor, and reachscale anthropogenic pressures on fish and macroinvertebrate assemblages in French rivers, Hydrobiologia 704: 375-388.

Morrice J.A., Danz N.P., Regal R.R., Kelly J.R., Niemi G.J., Reavie E.D., Hollenhorst T., Axler R.P., Trebitz A.S., Cotter A.M., Peterson G.S., 2008, Human influences on water quality in Great Lakes coastal wetlands, Environ. Manage. 41:347-357. 
Pawlewicz A., Bórawski P., 2013, Realizacja programu rolnośrodowiskowego $\mathrm{w}$ Polsce (The implementation of the agri-environmental programme in Poland), Rocz. Nauk. SERiA 15(2): 271-276.

Promper C., Puissant A, Malet J.-P., Glade T., 2014, Analysis of land cover changes in the past and the future as contribution to landslide risk scenarios, Appl. Geogr. 53: 11-19.

Ptak M., Ławniczak A.E., 2011, Changes in land use in the buffer zone of lake of the Mała Wełna catchment. Limnol. Rev. 12(1): 35-44.

Rembold F., Carnicelli S., Nori M., Ferrari G.A., 2000, Use of aerial photographs, Landsat TM imagery and multidisciplinary field survey for land-cover change analysis in the lakes region (Ethiopia), Int. J. Appl. Earth Observ. Geoinform. 2(3-4): 181-189.

Rindfuss, R. R., Walsh, S. J., Turner, B. L., Fox, J., Mishra, V., 2004, Developing a science of land change: challenges and methodological issues. Proceedings of the National Academy of Sciences of the United States of America, 101(39): 13976-13981.

Ruelland D., Levavasseur F., Tribotte A., 2010, Patterns and dynamics of land-cover changes since the 1960s over three experimental areas in Mali, Int. J. Appl. Earth Observ. Geoinform. 12: 11-17.

Ryding S.O., Rast W. (eds), 1989, The control of eutrophication of lakes and reservoirs. Man and the Biosphere Series. Vol. 1, UNESCO and Parthenon Publishing, Paris, pp. 314.

Slaymaker O., Spencer T., Embleton-Hamann C., 2009, Geomorphology and global environmental change, Cambridge Univ. Press, New York, pp. 468.

Snyder C.D., Young J.A., Villella R., Lemarie D.P., 2003, Influences of upland and riparian land use patterns on stream biotic integrity, Landsc. Ecol. 18(7): 647-664.

Strayer D.L., Beighley R.E., Thompson L.C., Brooks S., Nilsson C., Pinay G., Naiman R.J., 2003, Effects of land cover on stream ecosystems: Roles of empirical models and scaling issues, Ecosystems 6(5): 407-423.
Svoboda, N., Taube, F., Kluß, C., Wienforth, B., Kage, H., Ohl, S., Hartung, E., Herrmann, A. 2013, Crop production for biogas and water protection - A trade-off?, Agric.Ecosyst. Environ. 177: 36-47.

Tu J., Xia Z.G., 2008, Examining spatially varying relationships between land use and water quality using geographically weighted regression I: Model design and evaluation, Sci. Total Environ. 407: 358-378.

[USP] Urząd Statystyczny w Poznaniu (Statistical Office in Poznań), 2012, Charakterystyka gospodarstw rolnych w województwie wielkopolskim. Powszechny spis rolny 2010 (Characteristics of agricultural holdings in Wielkopolskie Voivodship. Agricultural Census 2010, pp. 277 (in Polish and English).

Williams M., Hopkinson C., Rastetter E., Vallino J., Claessens L., 2005, Relationships of land use and stream solute concentrations in the Ipswich River basin, Northeastern Massachusetts, Water Air Soil Pollut. 161: 55-74.

Woli K.P., Nagumo T., Kuramochi K., Hatano R., 2004, Evaluating river water quality through land use analysis and $\mathrm{N}$ budget approaches in livestock farming areas, Sci. Total Environ. 329: 61-74.

Valbuena D., 2010, Effects of farmers' decisions on the landscape structure of a Dutch rural region: An agent-based approach, Landsc. Urban Plann. 97: 98-100.

Verburg P., Eickhout B., Meijl H., 2008, A multi-scale, multi-model approach for analyzing the future dynamics of European land use, Ann. Reg. Sci. 42(1): 57-77.

Zwoliński Z., 1998, Geoindykatory w badaniach współczesnej dynamiki geosystemów (Geoindicators in studies of present-day dynamics of geosystems), [in]: Pękala K. (ed.), Główne kierunki badań geomorfologicznych w Polsce. Stan aktualny i perspektywy (The main directions of geomorphologic studies in Poland. Current state and perspectives), Wydaw. UMCS, Lublin: 223-227 (in Polish, English summary).

Zwoliński Zb., Kostrzewski A., Stach A., 2008. Tło geograficzne współczesnej ewolucji rzeźby młodoglacjalnej. W: L.Starkel, A.Kostrzewski, A.Kotarba, K.Krzemień (red.), Współczesne przemiany rzeźby Polski, Stow. Geomorf. Pol., IGiGP UJ, IGiPZ PAN, Kraków: 271-276. 